\title{
« John Stuart Mill on Wage Inequalities Between Men and Women »
}

\author{
$\underline{\text { Auteurs }}$ \\ Virginie Gouverneur \\ Document de Travail $n^{\circ} 2018-43$
}

Octobre 2018

Bureau d'Économie

Théorique et Appliquée

BETA

www.beta-umr7522.fr

@beta_economics

Contact :

jaoulgrammare@beta-cnrs.unistra.fr 


\title{
John Stuart Mill on Wage Inequalities Between Men and Women
}

\author{
Preliminary draft - Virginie Gouverneur ${ }^{1,2}$
}

\section{Code JEL : B1}

\begin{abstract}
A section of Mill's Principles (1848) is about women's low wages. Contemporary commentators who have studied it minimize its normative content. According to them, Mill's belief in the naturalness of the traditional sexual division of roles prevent him from proposing efficient remedies to male-female wage differentials and occupational segregation by sex. We propose another reading of Mill's analysis, as a protest against power relations which, pervading Victorian society, cause wage differences unjustified by differences in efficiency. Its focus is not occupational segregation by sex. Mill addresses the issue elsewhere, then identifying distinct causes of women's limited entry into skilled occupations.
\end{abstract}

Keywords: John Stuart Mill, gender pay gap, discrimination, occupational segregation by sex

\section{Introduction}

Few detailed analyses of John Stuart Mill's approach to wage inequalities between men and women have been proposed. Yet, such an analysis seems to us essential from two points of view. First, elements of Mill's study still seem relevant today and can enrich contemporary studies that focus on gender pay inequalities. In general, in modern approaches, the effect of social norms and custom on women's wages is rarely considered as a full-fledged factor. In Mill's analysis, the weight of custom, usage, and social norms (including that of the male breadwinner), appears as an essential cause of gender wage differences. Of course, the times are not the same and since the inequalities of wages between men and women have largely diminished. But old customs and norms, which have long prevailed in society, still persist today and continue to explain at least a part of the current wage differences between the sexes. It is therefore necessary to question the impact that they may have had at a given moment and that may have led to the persistence of their effects over time. Second, the approach developed by Mill is particularly interesting from the perspective of the history of ideas: on the question of women's wages, Mill appears as a real exception among his peers economists. In general, contemporary commentators recognize as a remarkable fact Mill's interest in the problem of women's low wages in his time. However, many of them expressed serious reservations about the scope of his analysis. For Michèle Pujol, the first economist to have addressed the issue of feminism and anti-feminism in the early days of English economic thought, Mill has the merit of having proposed in his Principles of Political Economy (1848) a study of the causes of women's wages that reflect "an understanding of the economic consequences of the specific social relations which affect women's economic status" (Pujol 1992, 27). Nevertheless, she criticizes Mill for having evaded the question of remedies that could help to reduce these inequalities (27). In a more recent article, Jennifer Ball (2001, 511-3) argues that for Mill wage differentials between men and women come primarily from occupational segregation by sex. Mill would thus suggest as the only remedy for these gaps the removal of laws restricting women's access to the labour market; an insufficient remedy to allow the full equalization of the wages of men and women because

\footnotetext{
${ }^{1}$ University of Strasbourg, University of Lorraine, CNRS, BETA, 67000, Strasbourg, France.

${ }^{2}$ University of Haute-Alsace, F-68100, Mulhouse, France.
} 
women's domestic duties prevent them from fully participating in the labour market. For Pujol as for Ball, Mill's analysis of women's wages is mainly limited by his belief in a natural basis of the traditional sexual division of roles in family, by which the man is the main breadwinner and the woman keeps the home and manages the family budget. These criticisms, although partly founded, give a truncated view of Mill's analysis. They do not sufficiently take into account the context in which Mill writes on this subject and ignore important constitutive elements of his study, thus underestimating Mill's contribution to the understanding of the gender pay gap and occupational segregation by sex. They minimize in particular the importance of the analysis' normative content, related to Mill's utilitarianism. The purpose of this article is to shed light on Mill's contribution through a critical rereading of his analysis as a real protest against gender ideologies and prejudices which permeate Victorian society and impact the labour market by inducing wage differences not justified by differences in efficiency. In order to better define and delineate the object of Mill's analysis, the first part aims to situate it in its context - characterized by a deep rootedness of gender inequalities. The second part consists to evaluate this analysis as it appears in 1848 in the first edition of Mill's Principles: what place does it give to gender stereotypes and women's subordination to men as explanatory factors of wage differences between men and women? While Mill has first of all developed a positive analysis that aims at identifying sources of wage discrimination against women in the labour market, it is possible, in the light of this analysis, to trace his normative analysis of wage inequalities due to discrimination ${ }^{3}$. Mill's study focuses on inequalities occurring in the competitive segments of the labour market. Thus, it leaves aside the question of wage differentials between the sexes due to women's difficulties of accessing skilled and gainful employment. However, Mill addresses the issue of occupational segregation outside of his paragraph, then comparing two possible sources of this segregation: male monopolies or women's specialization choices.

\section{A First Contribution to the Question of Women's Low Wages}

Set in context, Mill's analysis of women's low wages appears as a first theoretical contribution on this subject within liberal economics. As early as 1848, Mill devotes a paragraph of his Principles to women's low wages (Mill 1848, 394-6). His analysis appears as an exception from a double point of view: before Mill, no economist had devoted himself to examine so rigorously the problem of inequalities of wages between men and women; after him, it is only in the years 1880 that the issue will be posed again by liberal economists.

With the entry of women into the labour force at the time of the Industrial Revolution, philosophers and economists of the late eighteenth and early nineteenth century take a position on the participation of women in the labour market. In particular, their attention focuses on women's access to subsistence means or occupations adapted to their feminine qualities. The problem of pauperism, concomitant with industrialization, particularly affects women. In the $1780 \mathrm{~s}$, Jeremy Bentham, generally considered as the father of utilitarianism, explains that women are more affected by poverty than men because of less financial autonomy and higher unemployment, linked to a "peculiar disadvantage in finding an occupation"4 (Bentham 1782, 543; Cot 2003, 171-2; Bahmueller 1981, 16). He advocated

\footnotetext{
${ }^{3}$ The term discrimination is not used by Mill. It refers in this paper to its narrowest sense, that is a situation occurring when people with equal (actual or potential) productivity are treated differently on the basis of belonging characteristics such as "sex" or "race" (Gazier 2010,1).

${ }^{4}$ Bentham indeed affirms in the introduction of his Principles of Morals and Legislation that "(i)n point of pecuniary circumstances, according to the customs of perhaps all countries, she is in general less independent" (Bentham,1780, 58-59; cited by Cot $[2003,171])$.
} 
reserving for women certain occupations "particularly suited for the female sex"5. Shortly afterwards, Priscilla Wakefield advocates a general extension of economic opportunities open to women and opposes - without analysing them - gender inequalities in wages (Wakefield 1798, 151; Cot 2003, 194-200). She explains that women must have access to respectable, income-generating occupations, appropriate to the female character, which would enable them to escape poverty (Wakefield 1798, 164-75; Cot 2003, 197). At the same time, the French economist Jean-Baptiste Say addresses the issue of women's poverty. He considers that some occupations "hardening the heart or making bitter the character" should be closed to them while others, more adapted to their feminine qualities - cooking, sewing or hairdressing must be reserved for them in order that they can earn an honourable living (Say 1800, 47; Forget 2003, 214-7). He does not take into account the negative effect of the confinement of women in some occupations on their wages. According to Forget, "the analysis of gender that Say articulated in Olbie persisted as the foundation of the nineteenth-century analyses that argued, for example, that the 'natural wage' of women is lower than that of men because men must support a family, whereas women need only support themselves"6 (Forget 2003, 220).

After these early approaches dating from the late eighteenth century and early nineteenth, the issue will not be considered again during almost fourty years ${ }^{7}$. The industrial development of England continued and was accompanied by an increase in women's work outside the home or family business. The first laws restricting women's labour were introduced in the 1840s. Previously, only child labour was regulated through the Factory Acts. In 1842, the Mines and Collieries Act prohibited the underground work of women in coalmines. The Graham's Factory Act of 1844 limits the daily working hours of women to 12 hours. In 1847, a new law restricted this period to 10 hours $^{8}$. Debates then emerge among economists on the industrial legislation regulating women's work in factories and workshops. Mill positions himself as an opponent of these restrictive regulations. In his Principles (1848), he includes women as participants in the labour market and presents as illegitimate the restrictions affecting their labour. He undertakes in the same edition his detailed study of the causes of low wages for women. Barbara Bodichon, a prominent figure of Victorian feminism, will be the only economist of the time to react to Mill's analysis, although it will be indirectly and critically. She, who will be actively working to open jobs for women, will take up the issue of women's low wages in her 1857 Women and Work (Pujol 1992, 37-42). In this work, she criticizes Mill's position as it appeared in his essay On Marriage (1832). Mill wrote in this essay that, in a state of things where legal equality between the spouses would have been established, married women would not need to work effectively. Bodichon fought for

\footnotetext{
${ }^{5}$ Bentham, University College Mss., LXXXVII, 80; cited by Bahmueller $(1981,16)$ and Cot $(2003,172)$.

${ }^{6}$ Similarly, in his Treatise on Political Economy, Say defends the idea of a family income for the man. He argues that the male wage must allow the reproduction of labor and to cover the needs of the worker's wife and children. Women, on the other hand, only seek to supplement the family income. As a result, they only need a supplementary wage, which justifies the fact that their wages are lower (Say 1803, book II, 54-5; De Curraize and Hugounenq 2004, 197).

${ }^{7}$ Few socialist theories or under socialist influence of the first half of the nineteenth century - based in particular on the positions defended by the Saints-Simonians in France and by Robert Owen in the United Kingdom addressed the question of wage inequalities between the sexes. William Thompson and Anna Wheeler did it indirectly in 1824-25, arguing that in order to achieve full equality between men and women, including material equality, it is necessary for society to abandon the market economy and to adopt socialism - a system in which both production and reproduction would be taken into account and each would receive an equal share of the wealth generated through co-operation (Nyland \& Heenan 2003, 241-61; Thompson and Wheeler 1825).

${ }^{8}$ At the same time, feminist stances multiplied during the nineteenth century until the emergence of a genuine English "feminist movement" in the years 1850-1860, at the beginning of the Victorian era. Equal pay for men and women is not among the main demands of activist groups at the beginning of the movement. The inferiority of women's wages is often denounced as an injustice, but this does not give rise to any specific analysis of the problem. Attention was particularly focused on women's right to vote and access to the labour market.
} 
women's right to work and keep their own wages, including for married women $(1857,11$ 12). According to her, "women are placed in a great disadvantage in the market of work because they are not skilled labourers, and are therefore badly paid. They rarely have any training. It is the duty of fathers and mothers to give their daughters this training" (50-51). Aside from Barbara Bodichon's plea, Mill's attempt to denounce and explain wage inequalities between men and women did not find immediately a considerable echo in the world of economists. Several reasons can explain it. At the time, the position of women in wage labour was strongly questioned ${ }^{9}$. In addition, the issue of women's wages will remain a problem until the adoption of the first Married Women's Property Act in $1870^{10}$. The legal doctrine of the Coverture, then registered in the Common Law of England, implied the suspension of the legal existence of a woman at the time of her marriage, since it was then integrated with that of her husband. This doctrine attributed the status of feme coverte to the wife who, losing all legal capacity, could not go to court or sign any legal document such as a contract in her own name. She was deprived of all property, her goods and income being abandoned to the management of her husband, regardless of the extent of the property brought into the marriage. The Married Women's Property Act of 1870 stipulates that wages and property derived from the wife's work must be considered as her separate property ${ }^{11}$. Part of the effect of this measure was to protect the wages of working-class women by preventing their husbands, often represented as "good for nothing", from squandering their money in drink and gambling. Lastly, the condition and specific problems of working-class women will only be fully considered after the 1880 s, when the first women's labour unions were created, the demands of which being partly on workers' wages (Corvisy and Molinari 2008, 168-172; Lewis and Rose 1995) ${ }^{12}$.

It will be only with Alfred and Mary Paley Marshall that the issue of inequalities of wages between men and women will be again considered within liberal economics. The newlyweds will dedicate a chapter of their sole joint production published in 1879, The Economics of Industry, to the analysis of gender pay gaps ${ }^{13}$. But it will not be until the 1890s that the question becomes a real object of debates among economists. Then, various social or more theoretical approaches will be developed at this time (S. Webb 1891; Fawcett 1892; Smart 1892; Heather-Bigg 1894; Collet, 1899, 1902; Cadbury, Matheson and Shann 1906; Cannan

\footnotetext{
${ }^{9}$ See for example Friedrich Engels's study (1845) about the situation of the labouring classes and Lewis and Rose's history (1995) of the debates on women's work occurring all along the nineteenth century.

${ }^{10}$ Mill will not resume the question of women's low wages in The Subjection of Women, written in 1859 and published 10 years later, in 1869 . This can in part be explained by the fact that, in this work, he adopts a strategic position consisting to attract as many readers as possible to his demands for political and social rights for women. He adopts a short-term vision which allows him to put forward his demands for women's right to vote, married women's right to dispose of their property, women's right to freely access employment and education, without drowning them among other considerations. He leaves aside questions which would refer to long-term considerations such as population growth and wage differentials.

${ }^{11}$ The property brought by the wife into the marriage remained at the full disposal of the husband. It was not until the Married Women's Property Act of 1882 that the equity rules were extended to all married women's property, regardless of its origin or the time required for its acquisition (Caine 1997, 119, Griffin 2003, 80-1).

${ }^{12}$ In 1874, at the initiative of Emma Patterson, is born The Women's Trade Union League with the ambition of proving that women can improve their economic position by unionizing (Lewis and Rose 1995, 105-6). A decade later, in 1883, The Women's Co-operative Guild, affiliated to the Labor Party, advocated a peaceful transition from autocratic capitalism to democratic co-operation through the reunification of working-class housewives into consumers co-operatives. These labor organizations have their own demands, including reduced hours of work, higher wages, and maternity priviledges, but also share the broader ambitions of the middle class women's movement.

${ }^{13}$ Marshall will not resume the question in his Principles of Economics (1890). He will assert in this work that too high wages lead women to abandon their homes and neglect their duties (Marshall 1890, 727-8, 1920, 685). Thus, the analysis conducted in The Economics of Industry seems to reflect Mary Paley Marshall's ideas rather than those of her husband (see Gouverneur 2018, 7-8).
} 
1914). A second wave of theorization will take place during the First World War (Fawcett, 1916, 1918; Rathbone 1917; B. P. Webb 1914, 1919) and a third in the inter-war period, including two articles of Francis Ysidro Edgeworth published in 1922 and 1923.

It is therefore in an unfavourable context that Mill writes his paragraph on women's low wages. Several elements may explain his interest in this issue. In the line of Bentham, one of his most influential masters, he is preoccupied by the social condition of women, especially the difficulties they face to be financially independent or to earn sufficient wages to live without other resources. At the same time, the context has changed between the two authors. The increase of women's work runs counter to the ideology that women's place is at home. Mill reacts negatively to the regulations of women's work which condemn them to economic dependence. He fights also for the establishment of just laws as regards married women's property (Mill 1869, 86). The exceptional character of his study is representative of his general progressism on the subject of inequalities between men and women, largely related to his utilitarianism ${ }^{14}$. Initiated by Bentham and other utilitarians, including the socialist William Thompson, he fought very early for women's rights and the improvement of their condition. On the theoretical plan, he affirms the existence of narrow links between gender equality and the utility - or the greatest happiness for the greatest number - and progress of society. In Utilitarianism, published in 1863 , he devotes a chapter to the links existing between justice and utility, defending in particular the idea that the principle of utility implies in itself a principle of impartiality $(1863,91)$. The happiness of each individual, man or woman, must count as much as the happiness of another individual in the calculation of utility. This implies that all individuals have a right to equality of treatment. Mill thus advocates the equal treatment of men and women, equating "sex aristocracies" with a custom or an obsolete institution that must cease to be considered expedient and must be placed in rank of injustice:

"All persons are deemed to have a right to equality of treatment, except when some recognised social expediency requires the reverse. And hence all social inequalities which have ceased to be considered expedient, assume the character not of simple inexpediency, but of injustice, and appear so tyrannical, that people are apt to wonder how they ever could have been tolerated [...]."

(Mill 1863, 93)

In The Subjection of Women, written in 1859 and published in 1869, he advocates "perfect equality" between men and women, basing his plea mainly on utilitarian arguments (Mill $1869,1)$. The social progress goes hand in hand with the reduction of inequalities between the sexes, which must take place gradually, by taking into account the context and countering the weight of custom and old institutions $(2,36)$. The question is then whether women's right to equal treatment implies a right to wages equal to those of men. In other words, to what extent is the progress inseparable from the reduction of gender pay inequalities? The principle of equal treatment underlies Mill's study of women's low wages. It requires in the first place the implementation of the principle of pay equity. Mill's analysis, as it appears in 1848 in the first edition of the Principles, focuses on the phenomenon of wage discrimination against women, i.e. the fact that, in the labour market, "equal capacity is remunerated for women at a lower wage rate because of their group belonging" (Sofer and Havet 2002, 83).

\section{Equal Efficiency, Unequal Pay: an Analysis of Economic Discrimination}

Mill's study of women's low wages has both a positive and a normative side. It consists to identify the causes of the observed gender pay inequalities not justified by differences in

\footnotetext{
${ }^{14}$ Mill's beliefs in gender equality may have also been reinforced by the influence of the Socialists and by Harriet Taylor, her partner in life and in work. But these additional influences don't oust the closed links existing between Mill's utilitarianism and his defence of women's emancipation.
} 
productivity. At the same time, it brings into light sources of discrimination and obstacles to wage equity that have to be fought in order to eliminate these unjust wage inequalities. The reduction of the gender pay gap then appears as an inherent element of the society's progress.

\subsection{A Positive Analysis of the Inequalities of Wages Between Men and Women}

Mill's paragraph begins with the observation that women earn wages "generally lower, and very much lower, than those of men"15 (Mill 1848, 394). Throughout the paragraph he devotes to the gender pay gap, Mill reasons in terms of equal productivity of men and women. This has a positive aspect in the sense that Mill explains the inferiority of women's wages to those of men by causes other than that of a lower productivity. He argues that in their case the rule of equal pay for equal efficiency is rarely respected. He presents this phenomenon as the result of gender stereotypes and inequalities operating at all levels of society.

\section{The Weight of the Custom inducing Hierarchical Relationships between the Sexes}

Mill links the gender wage inequalities observed in his time in the industrial sector and in the domesticity to the position assigned to women in society and in family. His analysis of wage inequalities between men and women is thus inseparable from his analysis of the gender relations that prevail in the Victorian era. According to him, women's wages are not universally lower than those of men. In the case of occupations in which both sexes are employed, men and women "are not always unequally paid"16 (Mill 1848, 394-5). Indeed, women working in factories can "sometimes earn as much as men"17 (395. Italics added). For example, according to Mill, workers in handloom weaving are often paid by the piece, their efficiency being thus subject to a sure test ${ }^{18}$ (395). However, apart from this case, women often earn lower wages than men in the trades in which they work together. Here we take a different view from Jennifer Ball who argues that for Mill, women generally "earn" the same wages as men when they do the same job as they do (Ball 2001, 512). Mill does not argue that the rule of equal pay for equal efficiency applies in most occupations held by both men and women. He only mentions the example of hand-weavers: "In most kinds of weaving, women can and do earn as much as men" (Mill 1848, 394). It should be noted, however, that even in these types of occupations, it is not certain that women always received wages equal to those of men. Mill does not cite any statistical evidence in support of his remarks.

For Mill, only the custom can be at the origin of a state of things in which women receive unequal pay for equal efficiency. He indicates in his Principles two factors of regulation of wages in a context of free competition, that is not hindered by human interferences. Wages "may be regulated either by competition or by custom" (Mill 1848, 337). In some cases where

\footnotetext{
${ }^{15}$ At the time, women's wages were almost half those of men (Burnette 2008, 73; Honeyman 2000, 54; Corvisy and Molinari 2008, 167).

${ }^{16}$ Mill leaves aside the question of wage differentials in low-skilled "common" occupations which result from differences in productivity due to women's less physical strength. Studies have shown that mechanization has made it easier for women to enter the labour market (Thompson and Wheeler 1825, 183-4; Nyland and Heenan 2003, 257-8). Nevertheless, according to the economic historian Joyce Burnette, it would not have eliminated all the differences in men's and women's productivity in the industrial trades. For example, handloom weaving was more difficult for women, the machines being cumbersome (Burnette 2008, 138-71).

${ }^{17}$ The term "sometimes" was added by Mill in the third edition of the Principles, published in 1852.

${ }^{18}$ In his Principles, Mill reveals that he believes in equal efficiency of women and men for factory work in his criticism of the second benefit of the division of labour stated by Adam Smith (Mill 1848, 125-8). He then tries to show that specialization in a single type of task is not necessarily source of greater efficiency and, more generally, that efficiency depends less on the work process itself than on the habit, acquired by the worker, to operate according to a certain work process (Pujol 1992, 27-8). Thus, although women reveal characteristics, engendered by habit, more adapted to general occupations requiring to perform different tasks simultaneously, than to particularized works, they are not considered less "efficient" than men for "the uniformity of factory work" (Mill 1848, 128). They otherwise would not be so widely employed as factory workers.
} 
"there is nothing to restrict competition ... the result is not determined by competition, but by custom or usage" (239). While Mill generally presents custom as a punctual determinant of wages, he considers it as a rule in the case of the determination of women's wages (Ball 2001, 511). Far from using it as an abstract concept that only allows explaining the inexplicable, he gives a precise definition of it ${ }^{19}$. Mill indeed defines the "custom" or "usage" which affects women's wage rates as the product of gender stereotypes and the manifestation of unequal power relations between the sexes, based on the assignment of socially constructed roles. The inferiority of women's wages is explained by the custom which, "grounded either in a prejudice, or in the present constitution of society ... [makes] almost every woman, socially speaking, an appendage of some man, enables men to take systematically the lion's share of whatever belongs to both" (Mill 1848, 395. We underline). As Mill explains in The Subjection of Women, the position of women in society and in family is such that they are reduced to an "appendage to men" (Mill 1869, 141).

That being said, the main question for Mill is not about sectors that are almost equally occupied by both sexes, but occupations that are predominantly female. He argues that in these occupations, women's pay is "always" well below that perceived by men in occupations which require "equal skill" and are of "equal disagreeableness" ${ }^{20}$ (Mill 1848, 395). In the domestic service sector, which at the time comprises $50 \%$ of working women, the weight of custom is also responsible for the differences in wages observed between men and women ${ }^{21}$. According to Mill, the wages of domestic workers are far in excess of the market value of labour, and "in this excess, as in almost all the things that are regulated by custom, the male gets by far the largest share" 22 (Mill 1848, 395). Similarly, the economic historian Pamela Sharpe argues that in the nineteenth century in England wages of domestic women were fixed by custom (Sharpe 1996, 114).

Mill therefore gives a great role to custom in the gender pay gap observed in his time. A role minimized by Jennifer Ball who seeks to show in her study that, in Mill, occupational segregation is the root cause of gender pay inequalities (Ball 2001). Even more so with Barbara Caine, who totally excludes the custom from Mill's explanations of the gender pay

\footnotetext{
${ }^{19} \mathrm{~J}$. Burnette criticizes eighteenth- and nineteenth-century economists who emphasized custom as a major cause of wage differentials between men and women. According to her, they used this ambiguous term with multiple meanings to explain differences in wages which were in reality mainly due to differences in productivity (Burnette 2008, 1, 135). But Mill focuses in his analysis on differences in wages not due to differences in efficiency precisely to denounce the lack of pay equity and by giving a real content to the notion of custom.

${ }^{20}$ Mill's paragraph on gender wage differentials is part of the chapter on "the differences of wages in different enployments" (Mill 1848, chapter XIV, 380-99). According to Mill, these wage differentials, in a situation of free competition, may be linked either to a different degree of attractiveness or to natural monopolies over certain skills (Mill 1848, 380-9). However, Mill does not introduce such causes in his analysis of women's low wages, since he reasons in terms of equal productivity of men and women.

${ }^{21}$ On this point, Mill defends a distinct view from that of William S. Jevons who says in 1882, a decade after the publication of the last edition of Mill's Principles (1873), that in the domesticity sector women have been able to defend their interests as well as men and that the determination of wages through the operation of the laws of supply and demand guarantees that everyone receives the share due to him or her (Jevons 1882, 118).

${ }^{22}$ The excess in question is due to an employers' practice: "[...] most persons who can afford it, pay to their domestic servants higher wages than would purchase in the market the labour of persons fully as competent to the work required. They do this, not merely from ostentation, but also from more reasonable motives; either because they desire that those they employ should serve them cheerfully, and be anxious to remain in their service; or because they do not like to drive a hard bargain with people whom they are in constant intercourse with; or because they dislike to have near their persons, and continuality in their sight, people with the appearance and habits which are the usual accompaniments of a mean remuneration" (Mill 1848, 399). However, this practice does not imply that the average wage for paid domestic work is greater than the market value of that work (337). All domestic employees can not be paid above the market price, that is to say above the cost of a domestic worker of equal skill for the work required. Otherwise, it would limit the possibility of providing employment to the masses (398-9).
} 
gap (Caine 1994, 41). This underestimation of the role attributed to custom by Mill is all the more unjustified because custom appears as a decisive element in all the explanations which he gives for wage differences. As we will see below, Mill presents the male breadwinner norm as the cause of the gap existing in the subsistence wages perceived by men and women. At this occasion, he establishes a positive link between the population growth rate and the widening of the gender pay gap.

\section{The Effect of the Male Breadwinner Norm on the Subsistence Wages of Men and Women}

Mill adheres to the idea, conveyed at the time by the doctrine of the wages fund, that the remunerations distributed depend on the proportion between the capital devolved to the payment of workers and the number of workers. As a result, wages decrease when the labour supply increases and, in times of high competition in the labour market, wages tend towards their subsistence level. However, the increase in overall labour supply affects women's subsistence wages more than men's ones. Mill argues that a certain degree of superabundance of labour can lead, "as matters now stand", to women's wages being set at a lower minimum than men's wages (Mill 1848, 395). This inequality is explained by the "general custom" that makes the man the sole earner of the family or prevents the woman from contributing to the family income (396). While women's wages must allow only their own subsistence and no more, the minimum at which the densest competition can bring down men's wages is equivalent to the necessities required to support an entire family. A man's wage must be sufficient to allow him to maintain, in addition to himself, a wife and "a number of children adequate to keep up the population" (396). Even in cases where the wife "earns something", the total income, consisting of both wages, must be sufficient to support the parents and children (396). That's why, Mill tells us, lowest wages rarely appear in occupations that provide a livelihood for employees. This only happens in occupations held by women, who are considered economically dependent on a man ${ }^{23}$. Contrary to what contemporary commentators Caine and Coole affirm, Mill does not argue here for a family income for men (Caine 1994, 41; Coole 1988, 144; Ball 2001, 511). He seeks only to explain why the rule of equal pay for equal work does not apply in the case of subsistence wages received by men and by women.

The Impact of the Sexual Division of Roles on Wages in Traditionally Female Occupations

Finally, with regard to occupations predominantly held by women in which wages are regulated by competition, Mill presents occupational segregation as an important cause of women's low wages. He explains that it is the overcrowding of traditionally female jobs that leads to the inferiority of women's wages in these jobs compared to the wages of men in occupations requiring equal skills. Mill is thus the first, even before Millicent Garrett Fawcett and Francis Ysidro Edgeworth, often cited as references on this subject, to highlight the role

\footnotetext{
${ }^{23}$ The idea of a subsistence wage will be largely abandoned by economists who will develop a theory of wages based on marginal productivity. According to Ball, if this theory postulates that wages become lower when the supply of labor increases, it does not imply that such a fall affects particularly women's wages (Ball 2001, 511). Unlike this idea, Havet and Sofer mention the modern theory according to which when women's labor supply exceeds women's labor demand, wage gaps between women and men appear $(2002,92)$. In 1881, Alfred and Mary Marshall were already trying to explain in The Economics of Industry why, even when market forces operate, women's wages do not correspond to their marginal productivity. In addition, the standard of the male breadwinner will often be put forward to explain the pay gap between men and women. A. Marshall will argue in his Principles of Economics that a man must at least earn enough to meet the "necessaries" for his family's "efficiency", including sufficient freedom for his wife to perform her household duties (Marshall 1890, 123; 1920, 69). Francis Ysidro Edgeworth will explain that, because of the universally accepted male breadwinner norm, men must have a higher income in compensation for their role as breadwinner. In his view, therefore, free competition of women, which would result in equal pay for both sexes, is not desirable (Edgeworth 1922).
} 
of occupational segregation in gender pay gaps ${ }^{24}$ (Havet and Sofer 2002, 92). A large number of trades, considered unsuitable for women, were closed to them in the nineteenth century. Thus, although a much smaller number of women than men earn their living on their own, "the occupations which law and usage make accessible to them are comparatively so few, that the field of their employment is still more overcrowded" (Mill 1848, 395). Occupational segregation confines women to a small number of occupations, which are thus overburdened. To explain the impact of this phenomenon on women's wages, Mill uses economic theory. The inferiority of women's wages compared to men's ordinary wages is explained by the excess of labour force in traditionally female occupations, especially as a high degree of overcrowding may depress women's wages to a much lower minimum than those of men. Mill blames the "law" and "usage" which limit women's access to the labour market ${ }^{25}$. However, he does not say more about these two sources of barriers to women's entry into the labour market (395). The first five paragraphs of his chapter on "the differences of wages in different employments", including the fifth paragraph on women's low wages, are about cases of free competition, that is to say competition not hindered by human interference (396). It is therefore outside of his analysis of women's low wages that Mill specifies what are precisely the impediments to women's competition. He first denounces the laws restricting their work. According to him, while children's freedom of contracting may legitimately be restricted, particularly to protect them from overwork, it is not legitimate to limit women's freedom to compete in the labour market. They are just as capable as men of pursuing their personal interests $(394,952-3)$. Under the pretext of "protecting" women's interests, men - including those who make the laws, the Parliament being entirely masculine at the time - do not allow them to engage in other "careers" than marriage and motherhood (Mill 1848, 765, 1869, 48-9, 51-3). As for "usage", it presumably refers to the domestic ideology, according to which the place of women is at home (Mill 1848, 765; Lewis and Rose 1995, 91).

\subsection{A Normative Analysis of the Gender Pay Gap}

In his analysis of women's low wages, Mill endeavours above all else to clarify the causes of wage discrimination against women in the labour market. He does not explicitly position himself on the legitimacy or illegitimacy of these inequalities nor on the remedies to be applied to them. Nevertheless, he clearly presents the existence of wage gaps not justified by differences in productivity (or in talents and skills) as going against the principle that "equal efficiency" should lead to "equal pay" (Mill 1848, 396). This principle has an anchor in Mill's utilitarianism. It refers to the "highest abstract standard of social and distributive justice" as defined in Utilitarianism $(1863,91)$. Mill explains indeed that equal treatment must be given to the men and women who have deserved just as much from society:

"[...] we should treat all equally well (when no higher duties forbid) who have deserved equally well of us and [...] society should treat all equally well who have deserved all equally well of it, that is, who have deserved equally well absolutely. This is the highest abstract standard of social and distributive justice; towards which all institutions, and the efforts of all virtuous citizens, should be made in the utmost possible degree to converge. But this great moral duty rests upon a still deeper foundation, being a direct emanation from the first principles of morals, and not a mere logical corollary from secondary or derivative doctrines. It is involved in the very meaning of Utility, or the Greatest-Happiness Principle."

(Mill 1863, 91)

\footnotetext{
${ }^{24}$ Occupational segregation is still presented today as an important factor of wage inequalities between men and women (Havet and Sofer 2002, 92, Lemière and Silvera 2008, 7).

${ }^{25}$ In the editions of 1848 and 1849 , Mill used the term "custom", which he replaced by the term "usage" in subsequent editions.
} 
Since society receives an equal gain from workers whose return is equal (or whose services are equally useful), these workers must receive an equal gain from society (Mill 1863, 84-85). In other words, they are entitled to equal pay. Wage inequalities between men and women which don't result from a difference in efficiency are unfair and illegitimate. It therefore appears necessary to reduce them. Although Mill's analysis does not as such address the issue of remedies that would overcome wage discrimination against women, it implicitly suggests several solutions ${ }^{26}$. Mill first mentions remedies likely to work in the long run. Reducing the gender pay gap related to the status of women in society and in the family can only be achieved through a transformation of the relations between men and women.

\section{Replacing Hierarchical Relations by Just Relations}

Mill considers that the normal state of society is "society between equals" (Mill 1869, 1, 79). He advocates for more justice in the relations between men and women, starting with the family, which, designated by Mill as a school of despotism, must become a school of sympathy in equality $(66,81-2,148-53)$. Mill analyses marital relations as power relationships. While the husband has the absolute power - women, at the time, vowing obedience to their husband - the condition of the wife is similar to that of a slave (in particular, says Mill, in working-class households). These despotic relations must give way to a fair division of power between the spouses (71-3). It is only when the family will be formed on just foundation and will be made up of individuals equal in rights and in light that the gender relations at the level of society will tend no more to be regulated by the "law of the strongest" $(10,152)$. This progress will probably have an impact on the labour market through the elimination of the custom which, by making every woman the appendage of a man, allows men to appropriate the lion's share in "what belongs to both sexes" (Mill 1848, 395). More justice in the relation between the sexes would lead to more justice in the determination of the wages of men and women. That being said, this vision of justice putting men and women on an equal footing does not necessarily imply the total rejection of the male breadwinner model.

\section{Mill on the Male Breadwinner Norm}

In his explanation of the gap in men's and women's subsistence wages, Mill mixes two factors, namely overly high competition and the norm of the male breadwinner. This gap arises when the labour supply available on the labour market or in particular occupations is too abundant. Wages will rise above their subsistence level only if the overall labour supply decreases. To this end, Mill advocates the prohibition of child labour and the decline in the rate of population growth (Mill 1848, 370-9, 394, 952-3). The reduction of the population growth must occur through the lessening of the number of children per family; and the diminution of family size may be mainly promoted by better education and other factors related to women. According to Mill, women's work induces a decline in the fertility rate (765). This argument seems to apply in particular to the work of single women. Mill invokes a somewhat distinct argument as regards married women. In their case, it is about improving their status in the family so that their voice counts for more in the decision on the number of children to bring into world (372-3). As Mill explains, it is certainly not women who decide to have a high number of children. This distinct argument may be linked to the fact that, for Mill, married women's work has a negative impact by putting downward pressure on wages (Mill 1832, 75). Mill does not say clearly if the decline in the fertility rate would offset the rise of competition due to the participation of married women in the labour market. Does it

\footnotetext{
${ }^{26}$ We oppose Pujol on this point, according to whom Mill does not deal at all with the question of the remedies to be implemented to overcome the inferiority of women's wages to those of men (Pujol 1992, 27).
} 
mean that he adheres in fine to the norm of the male breadwinner, that he presents as the main cause of the gap between men's and women's subsistence wages?

In all likelihood, Mill cannot accept the norm of the male breadwinner. Many single women have to work to survive and earn too low wages because of the effects of this norm on all women's wages, particularly in traditionally female sectors (Mill 1848, 395-6). Moreover, if Mill asserts that married women's work has negative effects on wages, he considers that, given the context of the time and their condition in the family, they must work. In the pages preceding his paragraph on women's wages, he explains that in the industrial sectors where women and children work, the family income composed of the wages of both spouses and children is likely to be lower than the family income earned only by man in other sectors. This is particularly the case with the hand-loom weaving sector, where women often earn the same wages as men and where children are sent to work very early. Due to high competition in this sector, including that of individuals with other sources of income than work, individual wages are lower than those that men perceive in sectors where women and children do not work. Similarly, in the handloom weaving branches in which neither women nor children are employed, wages are higher than the common wage rate in this industry. Therefore, limiting married women's work would limit the effects of too much competition on wages. However, for Mill, this does not imply that women's freedom to work must be restricted. Even when the work of two spouses does not yield more than what would be earned by the man alone, "the advantage to the woman of not depending on a master for subsistence may be more than an equivalent" (Mill 1848, 394). In the unjust state of things that then prevails, it is better for married women to work to preserve their "dignity" (Mill 1869, 89, 182). On the other hand, it is necessary to limit child labour and to reduce the effect of their competition on wages. This would, even if Mill does not explicitly say so, compensate in part for the effects of married women's work. For Mill, nevertheless, it is not desirable as a permanent element in the condition of the working class that "the mother of the family (the case of a single woman is totally different) should be under the necessity of working for subsistence, at least elsewhere than in their place of abode" (Mill 1848, 394). This is probably why he does not mention the decline in the population growth rate as a factor likely to offset, in the long run, the effects of married women's work on wages ${ }^{27}$. While he warns against the diktat of the norm of the male breadwinner, he recommends the traditional sexual division of family roles, by which the man provides for the needs of the family, while the woman takes at her charge the education of the children and the domestic chores (Mill 1869, 87-8). This raises a question: will not the norm of the male breadwinner last as long as the traditional sexual division of roles continues? Is it not the effective participation of married women to the labour market and their systematic contribution to the family income that will lead to the disappearance of this norm? If Mill does not answer these questions, it cannot be concluded that he minimizes the effect of the norm of the male breadwinner on women's wages. First, the gap between men's and women's subsistence wages stems from socially prescribed roles, from a family model imposed by a "general custom" (Mill 1848, 396). In On Liberty, Mill warns well against the weight of custom, which must not be followed blindly by individuals (Mill 1859, 16, 105-7). Second, Mill does not present the traditional sexual division of labour as a family model that would be justified by natural differences between men and women (see on this point Gouverneur 2013, 760-2). This model should not be imposed by laws restricting women's work. The division of tasks in the family should be a matter of choice. Mill advocates the traditional sexual division of labour only as a recommendation, and only in case of the establishment of a just state of things, in which unjust marriage laws would have been abolished. In such context, women would be free to specialize in any occupation, including unpaid domestic work, that Mill

\footnotetext{
${ }^{27}$ Unlike Harriet Taylor in Enfranchisement of Women, published in 1851.
} 
presents as a full-time activity; and even then, it would belong to the spouses to decide which attribution of roles seems most appropriate to them, according to their private suitabilities (Mill 1869, 73). Mill adds that the one who brings the livelihoods must retain greater decision-making power, but he does not affirm that this one must absolutely be the man (734). As he affirms, the "inequality from this source does not depend on the law of marriage, but on the general conditions of human society, as now constituted" (73-4). Moreover, Mill leaves open the possibility of adjustments. The division of family roles, which should no longer be imposed by a norm, but be the result of a decision taken in common, is likely to evolve with customs and mentalities. Alongside these possible long-term evolutions, Mill mentions another remedy, with more immediate effects for women's low wages in traditionally female occupations. The opening of all types of industrial employments to women would reduce the effects of overcrowding due to occupational segregation.

\section{An Equal Access for Women to the Labour Market}

According to Mill, women's wages in traditionally female sectors will increase if competition decreases in these sectors. For this, it is necessary to prevent the cantonment of women in a small number of occupations. Mill advocates the removal of barriers to women's entry into the labour market. In the chapter of the Principles "On the Limits of the Province of Government", he argues that it should be an "object to give [to women] the readiest access to independent industrial employment, instead of closing, either entirely or partially, that which is already open to them" (Mill 1848, 953). The freedom of women to enter the various industrial trades would reduce the excess of labour force in traditionally female jobs so that women's wages in these jobs would increase. It is thus necessary to fight against "the law and usage" that closes most jobs to women (395). Women's work, unlike that of children, should not be the object of specific regulations and mustn't be regulated by preassigned social roles and hegemonic social norms. However, apart from these sources of barriers to women's entry into the labour market, Mill does not explicitly mention the role of male workers' associations in excluding women from a certain number of skilled trades ${ }^{28}$. His paragraph on women's low wages focuses on observable wage inequalities in the competitive segments of the low-skilled common labour market. Yet, there are non-competitive segments of the labour market where economic forces do not operate freely. At the time, men held a monopoly over skilled (crafts) and high-paid occupations ${ }^{29}$. Has Mill nothing to say about these professional barriers? Does he include them in what he calls the "usage"? The economic historian Joyce Burnette, in her study of "Gender, Work and Wages in Industrial Revolution Britain", argues that during the Industrial Revolution, women's labour regulations were not the main cause of the observed gender wage gap; it was men's labour organizations, which excluded women from many trades. Mill, unfortunately, does not address this issue in his study of women's low wages, in which he focuses on wage inequalities not due to differences in efficiency. He thus offers only a partial analysis of the effects of occupational segregation on women's wages. He considers the impact of horizontal segregation - that is the concentration of women in some

\footnotetext{
${ }^{28}$ It will be necessary to wait for the analysis of Alfred and Mary Paley Marshall (1881). Note that if workers get the right to meet in 1824, unions remain illegal until 1871 in England.

${ }^{29}$ Today, Burnette $(2008,228)$ and Rose $(1988)$ highlight the important role played by male associations in excluding women from skilled jobs in the nineteenth century in the United Kingdom. Burnette considers that the inequalities of wages between men and women observed in the early days of the Industrial Revolution are mainly explained by differences in productivity. These differences, according to her, were due in particular to the exclusion of women from occupations in which male labor associations predominated. She argues that government regulations are not a major source of occupational barriers, as they do not imply a total exclusion of women from affected jobs (Burnette 2008, 228-31). She considers that real barriers to entry appear "in less competitive parts of the labour market, where control of an important skill allowed the workers in that occupation to limit competition" (227-8).
} 
sectors - on women's wages in the trades reserved for them. But he leaves aside the issue of wage differentials between men and women due to differences in the type of occupations held, or, in other words, to productivity gaps. These ones may come from a gender division of labour deepened by women's exclusion from skilled trades or branches (Mill 1848, 128, 394). Does it mean that Mill underestimates the effect of differences in productivity on men's and women's wages? Not quite. First, Mill may voluntarily insist on the issue of pay inequity and the necessity to respect the principle of equal pay for equal work. He emphasizes that economic forces do not always operate when they should and that even when they actually operate, they are not sufficient to prevent pay inequity. Second, Mill does not completely elude the issue of women's limited entry into the skilled labour market. Elements related to this issue appear outside his paragraph on women's low wages and allow to trace his analysis of occupational segregation. In this one, a tension appears between justice and utility: while the right to a just treatment implies an equal freedom of choice of occupation for women, the effective participation of all women, including married women, to the labour market is not necessarily beneficial to society. As we will see, Mill resolves this tension by showing that the opening of all occupations to women will not necessary lead to the immediate entry of all women into the labour market.

\section{Equal Opportunities, Unequal Positions: Toward a Just(ified) Division of Labour?}

In modern theories of economic discrimination, wage inequalities due to occupational segregation are presented as unjustified or as justified (Havet and Sofer 2002, 86-7). For example, unequal wages between men and women may be unjustified when they come from a male monopoly over skilled and better-paid occupations in non-competitive parts of the labour market. On the other hand, followers of the beckerian human capital theory believe that wage inequalities are justified if they are induced by distinct human capital investments. Mill indirectly considers both sides of the question by putting into light different causes or origins of the occupational segregation by sex. He addresses the issues of male monopolies in the labour market and of women's specialization choices in a just state of things. His treatment of these issues highlights the importance that he gives to the circumstances and state of advancement of the progress. It is this, more than a class bias, that leads him to distinguish between the cases of working-class women and of wealthy women.

\subsection{Male Monopolies on Skilled Trades}

Mill's paragraph on gender wage inequalities is followed by a paragraph on wage differences due to the existence of non-competitive segments on the labour market (Mill 1848, 396-7). "Law and custom", according to Mill, can limit competition; in particular, workers combinations prevent the least qualified workers, especially hand-operated weavers, whose employments are overloaded, from gaining access to more qualified trades:

\footnotetext{
"Thus far, we have, throughout this discussion, proceeded on the supposition that competition is free, so far as regards human interference [...] But law or custom may interfere to limit competition [...] In some trades [...] to some extent, the combinations of workmen produce a similar effect. Those combinations always fail to uphold wages at an artificial rate, unless they also limit the number of competitors [...] It was given in evidence to the Hand-loom Weavers Commission, that this is one of the hardships which aggravate the grievous condition of that depressed class. Their own employment is overstocked and almost ruined; but there are many other trades which it would not be difficult for them to learn: to this, however, the combinations of workmen in those other trades are said to interpose an obstacle hitherto insurmountable."
}

(Mill 1848, 396. Italics added)

These "partial monopolies", Mill explains, may be desirable in the short run (Mill 1848, 796). As long as the improvement of the condition of the lower working-class members will 
not have had its effects in terms of limiting the population growth rate, some classes of artisans will have an interest in placing barriers to the entry of their trades to prevent the deterioration of their own condition (374). But when such reasons will no longer be relevant, neither do professional barriers. At a general level, Mill calls into question the existence of partial monopolies exercised by a small number of individuals on skilled trades to the detriment of the mass of the people. For him, human progress cannot continue until the privileges of a minority are prolonged:

"[E]very restriction of [competition] is an evil, and every extension of it, even if for the time injuriously affecting some class of labourers, is always an ultimate good. To be protected against competition is to be protected in idleness, in mental dullness; to be saved the necessity of being as active and as intelligent as other people; and if it is also to be protected against being underbid for employment by a less highly paid class of labourers, this is only where old custom, or local and partial monopoly, has placed some particular class of artisans in a privileged position as compared with the rest; and the time has come when the interest of universal improvement is no longer promoted by prolonging the privileges of a few."

(Mill 1848, 795-6)

Does Mill apply the same reasoning to women who, belonging to the higher working classes, are confined to low-skilled occupations? To what extent does he consider their exclusion from skilled trades as inefficient? Should not men's privileges be abolished? If skilled jobs were open to women, they might agree, accustomed to low wages, to work for lower wages than men in traditionally male occupations. But gradually, women's preferences could adapt to new circumstances, so that they would no longer represent unfair competition. Male monopolies would then become unjustified and incompatible with the general interest.

That being said, when Mill highlights the negative effects of the law and usage restricting women's access to the labour market on wages in traditionally female occupations, he seems to refer to something else than men's monopolies over high-paid trades. He explains in an ulterior chapter of his Principles that, from the point of view of justice, "law and custom" should not condemn women to economic dependence on men. Women must be able to "gain a livelihood" by other means than as wives and mothers:

\footnotetext{
"This most desirable result would be much accelerated by another change, which lies in the direct line of the best tendencies of the time; the opening of industrial occupations freely to both sexes. The same reasons which make it no longer necessary that the poor should depend on the rich, make it equally unnecessary that women should depend on men; and the least which justice requires is that law and custom should not enforce dependence (when the correlative protection has become superfluous) by ordaining that a woman, who does not happen to have a provision by inheritance, shall have scarcely any means open to her of gaining a livelihood, except as a wife and mother. Let women who prefer that occupation, adopt it; but that there should be no option, no other carrière possible for the great majority of women, except in the humbler departments of life, is a flagrant social injustice."
}

(Mill 1848, 765. Italics added)

All types of industrial occupations must be open to women to get them out of this relationship of dependence. The law and usage that impede women's entry into the labour market must be fought: "the ideas and institutions by which the accident of sex is made the groundwork of an inequality of legal rights, and a forced dissimilarity of social functions, must ere long be recognized as the greatest hindrance to moral, social, and even intellectual improvement"30 (Mill 1848, 765). In this manner, Mill denounces as unjust and a hindrance to

\footnotetext{
${ }^{30}$ In addition, Mill presents the social and industrial independence of women as a remedy for too high competition in the labour market, which puts downward pressure on the wages of low-skilled workers. Women's freedom of working would lead to a decline in the fertility rate and thus in the number of future workers: "I shall only indicate, among the probable consequences of the industrial and social independence of women, a great diminution of the evil of over-population. It is by devoting one-half of the human species to that exclusive function [to make children], by making it fill the entire life of one sex, and interweave itself with almost all the
} 
the progress the sexual division of social roles funded upon the idea that women's "nature" destines them to be only wives and mothers (Mill 1869, 38). By advocating women's freedom to enter the labour market, he appears to have in mind a purpose quite distinct from that of the equalization of wages of both sexes. He was already affirming in On Marriage that a woman must have enough to support herself, either because her parents gave her independent means of livelihood, or because she alone earns these means thanks to the education she received (Mill 1832, 74): "But whether so united or not, women will never be what they should be, nor their social position what it
should be, until women, as universally as men, have the power of gaining their own livelihood: until,
therefore, every girl's parents have either provided her with independent means of subsistence, or given her
an education qualifying her to provide those means for herself."

(Mill 1832, 77)

Women's freedom to work is necessary to give them the power to earn a livelihood and to support themselves (Mill 1848, 765). Their wages must be at least sufficient to enable them to be financially independent, to survive on their own, so that they do not have to marry or remain with a brutal husband ${ }^{31}$ (Coole 1988, 144-5; Ball 2001, 514-6; Pujol 1992, 26). The opening of all occupations to women would allow them to benefit from a real alternative to marriage or from the possibility of leaving their husbands in case of abuse. Mill's primary purpose is thus to convince his readers of the necessities to open all employments to women and to change the laws of marriage:

"But if marriage were an equal contract, not implying the obligation of obedience; if the connexion were no longer enforced to the oppression of those to whom it is purely a mischief, but a separation, on just terms (I do not now speak of a divorce), could be obtained by any woman who was morally entitled to it; and if she would then find all honourable employments as freely open to her as to men; it would not be necessary for her protection that during marriage she should make this particular use of her faculties."

(Mill 1869, 89)

But although he insists on the necessity to give to women the means of being independent, this does not mean that he is not concerned about male monopolies over skilled and high-paid occupations. In The Subjection of Women, he advocates women's "admissibility to all the functions and occupations hitherto retained as the monopoly of the stronger sex" (Mill 1869, 91). He then focuses on the case of middle-class and well-off women who don't have access to the lucrative occupations (as physicians, advocates or members of parliament). However, the arguments that he invokes are of a universal character. Mill indeed argues that it is both an injustice - women being deprived of the moral right of all human beings to choose their occupations "according to their own preferences, at their own risk" - and a damage for society to close high-skill functions for women $(32,94-5,182-87)$. First, women's exclusion from gainful employment is an unfair and tyrannical practice (94). As Mill explains, many men in the nineteenth century justify the prohibition of women's access to these occupations by the idea that women, by aspiring to such professions, "depart from their real path of success and happiness" (92). But in reality, the argument of protecting women's interests, according to Mill, hides a real aversion of men to live with equals. To allow women equal access to the labour market would entail the possibility that they would rather do anything

objects of the other, that the animal instinct [...] is nursed into the disproportionate preponderance which it has hitherto exercised in human life" (Mill 1848, 766).

${ }^{31}$ Mill, without going into the issue of divorce, advocates access to judicial separation for women: "It is only legal separation by a decree of a court of justice, which entitles her to live apart, without being forced back into the custody of an exasperated jailer-or which empowers her to apply any earnings to her own use, without fear that a man whom perhaps she has not seen for twenty years will pounce upon her some day and carry all off" (Mill 1869, 58). 
than marry if this means that they must submit to a master. In other words, men who "have a real antipathy to the equal freedom of women" are afraid that they will demand conditions of equality in marriage (51-2):

"[...] I believe that their disabilities elsewhere are only clung to in order to maintain their subordination in domestic life; because the generality of the male sex cannot yet tolerate the idea of living with an equal. Were it not for that, I think that almost everyone, in the existing state of opinion in politics and political economy, would admit the injustice of excluding half the human race from the greater number of lucrative occupations, and from almost all high social functions; ordaining from their birth either that they are not, and cannot by any possibility become, fit for employments which are legally open to the stupidest and basest of the other sex, or else that however fit they may be, those employments shall be interdicted to them, in order to be preserved for the exclusive benefit of males."

(Mill 1869, 91. Italics added)

Second, Mill puts forward also economic arguments to justify the removal of the monopolies exercised by men over lucrative occupations. Opening occupations previously closed to women would increase the overall efficiency of work. Allowing women to choose the occupation which best suits their faculties would "doubling the mass of mental faculties available for the higher service of humanity"32 (Mill 1869, 32-3, 48-9, 153-4). In this way, everyone would specialize in the activity to which his or her talents are most suited. Vice versa, if women are less able than men to perform certain jobs, the laws of competition will prevent them from entering these jobs (93). It is necessary to let them trying in order that they discover by and for themselves what they can do (48). The opening of occupations to women would also stimulate the intellect of competitors through a system based on merit rather than birth privileges $(95,154)$. Even if the extension of competition induced by women's freedom of choice of occupation would "for the time" affect men, the suppression of male monopolies would be "an ultimate good" (Mill 1848, 795).

Mill is aware of men's reluctance to the opening to women of "all honourable employments and of the training and education which qualifies for those employments", both because of a characteristic shared by all individuals, the fear of competition, and because of men's fear of equality in marriage (Mill 1869, 148). Partly by pragmatism, he speculates on what would be the choices of women in a just state of things. It appears that, in the context of the time, women's effective participation to the labour market would remain limited since the majority of them would continue to invest more in family life. Mill, implicitly, presents women's specialization choices and investments in human capital as determinants of the occupational segregation by sex. Moreover, in his approach to women's specialization choices, he takes into account the context of the time and the "effect" on women's preferences and abilities "of the differences in their education and circumstances" (98). Although he does not identify directly the lack of sharing of domestic chores with a discriminatory social practice, it appears as a basic assumption of his model and as one of the circumstances which affect women's choices and may lead them away from skilled, remunerative occupations ${ }^{33}$.

\footnotetext{
${ }^{32}$ The increase of the overall labor efficiency, by leading to productivity gains, would promote economic growth and, thereby, the increase of the wages fund. This would result in an increase of the wages of men and women in low-skilled trades.

${ }^{33}$ Modern theories of economic discrimination exclude discriminatory social practices from their analytical framework, even if they recognize that the lack of sharing of the domestic tasks limits women's ability to reconcile private and professional life. They consider as "out of the scope of economic discrimination all the differences which derive from male/female differences in choices, preferences or social roles, as long as they do not result from a constraint: differences in productivity justifying, from an economic point of view, differences in wages can come from the choice of a priority investment in family life rather than in professional life. This may result in less investment in initial education" (Havet and Sofer 2002, 84. Our translation). Economic discrimination is due to obstacles occurring at the level of the labour market or education.
} 


\subsection{Mill's Conjectures on Women's Specialization Choices}

We have already seen that, for Mill, in the unjust state of things which then prevails, most women should rather do anything other than marry if this means that they must submit to a master (Mill 1869, 51). Similarly, Mill believes that " $[t]$ he power of earning is essential to the dignity of a woman, if she has no independent property" (Mill 1869, 89). Married women must work in order to enhance their value in the eyes of their husband, even if "it enables him still farther to abuse his power, by forcing [his wife] to work, and leaving the support of the family to her exertions to work, while he spends most of his time in drinking and idleness" (Mill 1848, 394, 953, 1869, 88). On the contrary, Mill imagines a just state of things in which women could have access to all occupations already open to men and where a fair marriage contract would have been established. Women could then freely choose to specialize in paid work outside the home or in unpaid work at home. In Mill's model, the lack of sharing of domestic tasks appears as a contextual element to be taken into account. He argues that, when the wife works, "[t]he care which she is herself disabled from taking of the children and the household, nobody else takes" (Mill 1869, 88). Thus, married women's work is detrimental to children's care and education and to the management of the household and family budget: "those of the children who do not die, grow up as they best can, and the management of the household is likely to be so bad, as even in point of economy to be a great drawback from the value of the wife's earnings" (88). But these negative consequences, according to Mill, would be avoided in a just state of things. Women's freedom of choice of occupation, along with equality in marriage, would not lead to the immediate and massive entry of all women on the labour market. When Mill makes his "conjectures" on what would be women's specialization choices in just circumstances, he does not question the traditional sexual division of labour at home $(42,125)$. But he considers it as a circumstance influencing women's choices. Given the lack of sharing of domestic tasks, it is as if women, by choosing to marry, choose a career among all those open to them, at least until that their children leave home.

Mill explains that some women, not inclined to marriage, would always prefer to specialize in an occupation on the labour market. They will in this case invest in the human capital necessary to exercise the chosen profession. This would concern in particular women who, "having no special vocation for married life, or preferring another employment of their faculties (as many women even now prefer to marriage some of the few honourable occupations within their reach), have spent the best years of their youth in attempting to qualify themselves for the pursuits in which they desire to engage" (Mill 1869, 185; see also $1832,76)$. Mill advocates the access of women to training and education qualifying them for "all honourable employments" (Mill 1869, 148). These remarks suggest that only women who would choose single life could specialize in an occupation that requires a significant investment in human capital. Would many women make that choice? It is likely that few women would prefer to specialize in an activity outside the home if it implies that they must remain single. And indeed, as Mill affirms, it is not to be feared that women will turn away from family life and home. He makes the hypothesis that, in a just state of things, most women would specialize in unpaid domestic activity rather than in a career outside the home (Gouverneur 2013, 760-2). According to him, in the society as it is then constituted, the aptitudes and preferences of women would rather direct them toward the household management and education of children. It is at this time the occupation "for which they are most fit" and "in which there is nobody to compete with them" (Mill 1869, 49, 93). However, Mill's hypothesis is based on the observation of women's behaviour in a context in which all the force of education is used to teach them that they are made only for one function, maternity and caring for others $(85,143,154)$. Since their character has been shaped, their abilities built and their preferences internalized, it is impossible to obtain certitudes on the 
behaviour that they would adopt in a different context. Their specialization choices are the result of particular circumstances rather than a reflect of their nature.

Mill does not a priori include in women's circumstances the lack of sharing of the domestic tasks as a social norm impacting their decisions. Yet, it would force women - not men - to choose between a family life and a career on the labour market. He also fails to mention other factors that may influence women's choices. As long as women's wages will be generally lower than those of men, choosing single life would force women to accept a lower standard of living than they would obtain through marriage. As regards married women, the traditional sexual division of labour will remain the most favourable arrangement as long as the wages that they can gain will be lower than those of their husbands ${ }^{34}$. In this case, women marrying would be obliged to give up any activity "incompatible" with household work, what will limit their interest in investing in other domains than family life (Mill 1869, 89). Mill, nevertheless, mentions some possibilities to increase women's ability to conciliate domestic tasks with an outside career. He affirms that married women who are able to reconcile the household work with another occupation - for which they would have a special vocation - could, notwithstanding marriage, work outside the home (89-90). All wives would not be confined to child rearing and housework. It would be the case in households who have the means to recruit paid domestic servants to perform household chores and private teachers for school-aged children ${ }^{35}$ (Mill 1832, 75-6). However, Mill does not raise the question of hiring nurses, and in The Subjection of Women, he seems unfavourable to the delegation of the management of the family budget to domestic servants, which he considers as a source of "waste" (Mill 1869, 136-7, see also 1848, 138). In the case of working-class women, they will have no choice but to take care of household chores, as well as caring and raising children. Mill does not propose any form of socialization of household and educational tasks, nor any system of public or employers' crèches (Pujol 1992, 30; Ball 2001, 522-3). Thus, it is clear that, without a sharing of domestic chores, few married women, apart from a minority able to reconcile private and professional life, would be able to work outside the home; even less to occupy qualified jobs or remunerative functions for which they would have spent the necessary time to train. This echoes Gary Becker's conclusion that women choosing to marry do not have an interest in investing in human capital exploitable on the labour market (Becker, 1981, 1985). Few women choosing marriage would devote several years of their youth to training in another occupation. Mill only affirms that married women could, with an appropriate education, apply the talents they have acquired in the family to "a less contracted scale" (Mill 1869, 184-5).

But while Mill does not clearly admits that the traditional sexual division of family roles limits women's ability to specialize in an activity outside the home, he does not oppose the idea that the family model can evolve, so that women could more easily reconcile family and

\footnotetext{
${ }^{34}$ It is interesting to compare Mill's model to the Beckerian theory of the traditional sexual division of labor in the household justified by the comparative advantages of men and women. According to this theory, biological differences between the sexes imply that women are more efficient than men in maternal, educational and domestic tasks. In addition, the inferiority of women's wages to those of men, partly due to the fact that women invest primarily in family life, explains that married women leave the labor market and that it is the father who earns the family income. That being said, at least one fundamental difference opposes Mill and Becker. Mill does not present the traditional division of roles as being justified by natural differences between the sexes.

${ }^{35}$ The traditional sexual division of labor in the household is not necessarily an efficient arrangement if we refer to the position advocated by Mill in On Marriage (Ball 2001, 522). Indeed, for Mill, it is "absurd to set one-half of the adult human race to perform" educational tasks "on a small scale", while teachers trained for this purpose will be more efficient (Mill 1832, 75). Women play an essential role in the moral and emotional education of children, but this role is not a real work, which would be incompatible with an outside activity (76). It is only when a private teacher can not be hired that the mother becomes the "natural teacher" of her children (76). Mill also explains that it would be better to delegate the household tasks to specialized workers (75). Thus, the commodification of household chores would be more efficient than their fulfillment by the wife.
} 
professional life. First, he links the difficulties of working-class mothers to reconcile their domestic work with work outside the home to the fact that they have a high number of children, which results in a "domestic drudgery" (Mill 1848, 372, 953). The decrease in the fertility rate would reduce their household work and facilitate their access to employment. At the same time, it would lead to a diminution of the labour force counterbalancing the negative effect of the entry of married women into the labour market on individual wages. Second, while it is true that, in The Subjection of Women, Mill preconizes the traditional sexual division of labour within the household in a just state of things, he does not present it as a family model based on natural differences between men and women but rather as a modifiable circumstance $^{36}$. The traditional sexual division of labour is an arrangement among others; a form of power-sharing that can be adopted by some households at a given moment, without constituting a universal and timeless arrangement:

\begin{abstract}
"The natural arrangement is the division of powers between the two $[\ldots]$ any change of system or principle requiring the consent of both $[\ldots]$ The division of rights would naturally follow the division of duties and functions; and that is already made by consent, or at all events not by law, but by general custom, modified and modifiable at the pleasure of the persons concerned."
\end{abstract}

(Mill 1869, 72-3)

Therefore, a sharing of domestic tasks is not inconceivable with the evolution of mentalities and the modification of the relations between the sexes. Women will certainly be better able to defend their own interests once they will have access to the labour market and will enjoy legal equality with their husbands. In particular, it will allow them to gain more weight in the decisions of the household, including that of the sharing of household chores. With the progress of society, especially the advancement of gender equality, the division of labour at home and on the workplace is likely to change.

\title{
5. Conclusion
}

With his analysis of women's low wages, Mill offers a first liberal contribution to the question of wage differences between men and women. In a context where prejudices against women and the ideology that their place is at home predominate, he shows a real interest in the situation of women in the labour market. This interest stems from a broader concern for the status of women in society and in the family. Mill denounces in particular the relations between men and women that prevail in Victorian society. He analyses them as power relations and argues that despotic relations between the sexes must give way to relationships based on justice, starting in the sphere of the family. His study of women's low wages is a continuation of his argument in favour of greater justice for women. In its positive side, this analysis aims to explain the differences in wages observed between the sexes at the time. But it also has a normative side. It can indeed be seen as an additional attempt by Mill to denounce the domination of men over women. Understood thus, its objective is not the complete equalization of the wages of men and women. Its primary focus is on highlighting the repercussions on the labour market of hierarchical gender relations and predetermined gender roles. Thus, it doesn't consist to analyse the differences in wages between men and women that would be explained and justified by differences in productivity, but to clarify the causes of wage discrimination against women. Mill situates these causes mainly in male domination and the sexual division of social functions. He advocates equal treatment between men and women, this requiring profound changes. Changes that include, in addition to the

\footnotetext{
${ }^{36}$ We thus adopt a different position from Pujol and Ball, who argue that Mill's lack of a proposal for sharing domestic chores or of an alternative form of performing household and educational tasks stems from his belief in natural differences between men and women (Pujol 1992, 30, 34-6; Ball 2001, 519, 521).
} 
replacement of despotic relations by just relationships between men and women, the elimination of the diktat of the general opinion and norms (including the standard of the male breadwinner) and the free access of women to the labour market. In suggesting remedies for discrimination against women in the labour market, Mill is guided by the principle of equity or of just treatment, according to which, in a competitive context, women's wages in the trades which are open to them should be equal to those of men in trades which require equal faculties. Mill does not have in view the entire equalization of the wages of men and women, which would require the access of women to the trades that are then closed to them. Thus, his analysis leaves aside the question of gender pay inequalities due to differences in skills and occupied trades or, in other words, to differences in productivity. It is outside his paragraph on women's low wages that there are elements that could shed light on Mill's position regarding the entry of women into skilled and remunerative occupations. Implicitly, Mill mentions two factors that may limit women's access to higher-paying jobs. First, the existence of non-competitive segments on the labour market, that some modern theories present as a case of economic discrimination. Second, women's specialization choices, which are in part conditioned by the situation of women in Victorian society and discriminatory social practices. Mill, in both cases, makes a distinction between the women of the working class and the women of the middle and upper classes. When he addresses the issue of the monopolies exercised by men in the labour market in The subjection of women, his focus is on the case of middle-class and well-off women. He seems less concerned by the situation of working-class women, excluded at the time from many professions by the predominantly male labour organisations. But several reasons can explain it. As cheap labour force, women are likely to represent a threat for men's wages, at least as long as they accept lower wages. Moreover, the opening of occupations to women must first and foremost enable them to earn a livelihood, even if it may be only a first step towards access to higher wages. Mill's ambivalence on the case of working-class women also appears with regard to women's specialization choices in a fair state of things. If he explains that women preferring celibacy will invest in human capital that can be valued in the labour market, he does not explicitly propose to improve the access of working-class women to technical education. As for married women, they could have a career in the labour market provided that they can reconcile it with their domestic chores, what seems difficult for working-class women who cannot delegate the household work to domestics. Nevertheless, the decrease in the number of children, the evolution of the division of tasks in the home, are likely to facilitate in the future women's access to better-paid jobs. We will find the same type of interrogation in Edgeworth as in Mill. On the one hand, unequal wages between men and women run counter to the principle of pay equity; on the other hand, a significant part of these inequalities and occupational segregation by sex are closely related to the position of women in the family. But Edgeworth will draw opposite conclusions in terms of the necessity of reducing gender pay inequalities and opening up occupations for women. A future study would be to compare his position and arguments with those of Mill.

\section{References}

Bahmueller, Charles F. 1981. The National Charity Company: Jeremy Bentham' Silent Revolution. Berkeley, Los Angeles: University of California Press.

Ball, Jennifer. 2001. "J. S. Mill on Wages and Women: A Feminist Critique". Review of Social Economy LIX(4): 509-527.

Becker, Gary. 1981. A Treatise on the Family. Cambridge: Harvard University Press. 
Becker, Gary. 1985. "Human Capital, Effort, and the Sexual Division of Labor". Journal of Labor Economics 3(1): S33-S58.

Bentham, Jeremy. 1780. An Introduction to the Principles of Morals and Legislation, New York: Hafner Press, Macmillan, 1948.

Bentham, Jeremy. 1782. Principles of Penal Law. In Bentham, Works, Vol. 1, 365-580.

Bentham, Jeremy. [1838-1843]. The Works of Jeremy Bentham. Edited by John Bowring. Edinburgh: William Tait.

Bodichon, Barbara Leigh Smith. 1857. Women and Work. Introduction by Catharine M. Sedgwick. New York: C.S. Francis, 1859.

Burnette, Joyce. 2008. Gender, Work and Wages in Industrial Revolution Britain. New York: Cambridge University Press.

Cadbury, Edward, M. Cecile Matheson, and George Shann. 1907. Women's Work and Wages: A Phase of Life in an Industrial City (1906). Chicago: University of Chicago Press.

Caine, Barbara. 1994. "Feminism and Political Economy in Victorian England - or John Stuart Mill, Henry Fawcett and Henry Sidgwick Ponder the 'Woman Question"'. In Groenewegen (1994), 25-45.

Caine, Barbara. 1997. English Feminism 1780-1980. Oxford: Oxford University Press.

Cannan, Edwin. 1914. Wealth, A Brief Explanation of the Causes of Economic Welfare. London: P.S. King.

Collet, Clara Elizabeth. 1902. "Women's work". In Charles Booth, The Life and Labour of the People of London. London : Macmillan and Co. Poverty 4 : 256-327.

Collet, Clara Elizabeth. 1902. Educated Working Women: Essays on the Economic Position of Women Workers in the Middle Classes. London: P.S. King.

Coole, Dianah. 1988. Women in Political Theory: From Ancient Misogyny to Contemporary Feminism. Brighton: Wheatsheaf Books Limited, Boulder: Lynne Rienner Publishers Inc.

Corvisy, Catherine-Emilie and Véronique Molinari. 2008. Les femmes dans l'Angleterre victorienne et édouardienne. Paris: L'Harmattan.

Cot, Annie L. 2003. "'Let There be no Distinction Between the Sexes': Jeremy Bentham on the Status of Women". In Dimand and Nyland (2003), 165-193.

De Curraize, Yves, and Réjane Hugounenq. 2004. "Inégalités de salaires entre femmes et hommes et discrimination". Revue de l'OFCE No. 90, July.

Dimand, Robert and Nyland, Chris. 2003. The Status of Women in Classical Economic Thought. Northampton et Cheltenham: Edward Elgar.

Edgeworth, Francis Ysidro. 1922. "Equal Pay to Men and Women for Equal Work". The Economic Journal 32(128): 431-457.

Edgeworth, Francis Ysidro. 1923. "Women's Wages in relation to Economic Welfare". The Economic Journal, 33(132): 487-495.

Engels, Friedrich. 1845 [1892]. The Condition of the Working Class in England in 1844. Preface written in 1892 by Frederick Engels. Edited by David Price. London: Geo. Allen \& Unwin, 1892.

Fawcett, Millicent Garrett. 1892. “Mr. Sidney Webb's Article on Women's Wages". Economic Journal 2(5): 173-6.

Fawcett, Millicent Garrett. 1916. "The Position of Women in Economic Life". In After-War Problems, by the Earl of Cromer, Viscount Haldane, the Bishop of Exeter, Alfred Marshall and al. Edited by W. H. Dawson. London: Allen and Unwin.

Fawcett, Millicent Garrett. 1918. "Equal Pay for Equal Work". Economic Journal 28(109): 16.

Forget, Evelyn L. 2003. "The Market for Virtue: Jean-Baptiste Say on Women in the Economy and Society". In Dimand and Nyland (2003), 206-23. 
Gazier, Bernard. 2010. "La discrimination économique est-elle soluble dans la complexité". Revue de l'OFCE 3(114): 45-64.

Gouverneur, Virginie. 2013. "John Stuart Mill and William Stanley Jevons on the Traditional Sexual Division of Labour: is Gender Equality Efficient?". European Journal of the History of Economic Thought 20(5) : 741-775.

Gouverneur, Virginie. 2018. "Harriet Taylor Mill, Mary Paley Marshall and Beatrice Potter Webb: Women Economists and Economists' Wives". In Robert Dimand and Kirsten Madden, Routledge Handbook of the history of women's economic thought, 73-89.

Griffin, Ben. 2003. "Class, Gender, and Liberalism in Parliament, 1868-1882: The Case of The Married Women's Property Acts". The Historical Journal 46(1): 59-87.

Groenewegen, Peter. 1994. Feminism and Political Economy in Victorian England. Aldershot and Brookfield: Edward Elgar.

Havet, Nathalie and Catherine Sofer. 2002. "Les nouvelles théories économiques de la discrimination". Travail, Genre et Sociétés No. 7: 83-115.

Heather-Bigg, Ada. 1894. "The Wife's Contribution to Family Income”. Economic Journal 4(13): 51-8.

Honeyman, Katrina. 2000. Women, Gender and Industrialisation in England, 1700-1870. New York: St. Martin's Press.

Lemière, Séverine et Rachel Silvera. 2008. "Les multiples facettes des inégalités de salaires entre hommes et femmes". In A. Cornet and J. Laufer, Genre et Ressources Humaines. Vuibert editions, 2008.

Lewis, Jane and Rose, Sonya O. 1995. "Let England Blush' Protective Labor Legislation, 1820-1914". In Wikander and al. (1995), 91-124.

Marshall, Alfred and Mary Paley Marshall. 1881. The Economics of Industry, $2^{\text {nd }}$ edition ( $1^{\text {st }}$ edition: 1879). London: Macmillan and Co.

Marshall, Alfred. 1890. Principles of Economics, $1^{\text {st }}$ edition. London and New York: Mcmillan and Co.

Marshall, Alfred. 1890. Principles of Economics, $8^{\text {th }}$ edition. London: Macmillan, 1920. Reproduced as the first volume of the $9^{\text {th }}$ edition edited by C. W. Guillebaud. London, Macmillan, 1961.

Mill, John Stuart. 1832. Essay on Marriage. In Rossi (1970), 67-84.

Mill, John Stuart. 1848. Principles of Political Economy, $7^{\text {th }}$ ed., 1871. In Collected Works, Vol. II \& III. Edited by J. M. Robson. Toronto: University of Toronto Press, 1965.

Mill, John Stuart. 1859. On Liberty. London: Longman, Green \& Co.

Mill, John Stuart. 1863. Utilitarianism. London: Parker, Son and Bourn, West Strand.

Mill, John Stuart. 1869. The Subjection of Women, $3^{\text {rd }}$ edition. London: Longmans, Green \& Co., 1870.

Mill, John Stuart. 1873. Autobiography. In Collected Works, Vol. I. Edited by John M. Robson and Jack Stillinger. Toronto: University of Toronto Press, London: Routledge and Kegan Paul, 1981.

Mill, John Stuart. [1963-1991]. The Collected Works of John Stuart Mill. Edited by John M. Robson. Toronto: University of Toronto Press, London: Routledge and Kegan Paul.

Nyland, Chris and Tom Heenan. 2003. William Thompson and Anna Doyle Wheeler: A Marriage of Minds on Jeremy Bentham's Doorstep. In Dimand (2003), 241-261.

Pujol, Michèle A. 1992. Feminism and Anti-Feminism in Early Economic Thought. Preface written by Janet A. Seiz. Cheltenham and Northampton: Edward Elgar, 1998.

Rathbone, Eleanor. 1917. "The Remuneration of Women's Services". Economic Journal 27(105): 55-68.

Rossi, Alice S. 1970. Essays on sex equality. Chicago: The University of Chicago Press. 
Say, Jean-Baptiste. 1800. Olbie, ou essai sur les moyens de réformer les moeurs d'une nation. Paris: Déterville.

Say, Jean-Baptiste. 1803. Traité d'Economie Politique - Livre II. Paris: Calmann-Lévy, 1972. Numerical version produced by J.-M. Tremblay, collection "Les classiques des sciences sociales", 2002.

Sharpe, Pamela. 1996. Adapting to capitalism: Working Women in the English Economy, 1700-1850 (Studies in Gender History). New York: St. Martin's Press, 1996.

Smart, William. 1892. "Women's Wages". Proceedings of the Philosophical Society of Glasgow, 1891-2, Vol. 23: 87-105. Glasgow: John Smith and Son.

Taylor Mill, Harriet. 1851. Enfranchisement of Women. In Rossi (1970), 89-121.

Thompson, William and Anna Wheeler. 1825. The Appeal of one Half the Human Race, Women, against the Pretension of the Other Half, Men, to Retain them in Political, and Thence in Civil and Domestic Slavery, in Reply to a Paragraph of Mr Mill's Celebrated "Article on Government". London: Richard Taylor, Shoe-Lane.

Wakefield, Priscilla. 1798. Reflections on the Present Condition of the Female Sex, with Suggestions for its Improvement. London: J. Johnson and Darton and Harvey.

Webb, Beatrice Potter. 1914. "Personal Rights and the Woman's Movement, v. Equal Remuneration for Men and Women". The New Statesman 3(69): 525-7.

Webb, Beatrice Potter. 1919. "Minority Report". War Cabinet Committee on Women in Industry, Cmd 167.

Webb, Sidney. 1891. "The Alleged Differences in the Wages Paid to Men and Women for Similar Work". Economic Journal 1(4): 639-58.

Wikander, Ulla, Alice Kessler-Harris, and Jane Lewis. 1995. Protecting Women: Labor Legislation in Europe, the United States, and Australia, 1880-1920. Urbana and Chicago: University of Illinois Press. 